\title{
Standardization of Dose and Delivery of Oxytetracycline against Streptococcus agalactiae Infection in Genetically Improved Farmed Tilapia (GIFT)
}

Kishan Kishorchandra Kalaria, Kollanoor Riji John¹, Mulloorpeedikayil Rosalind George

10.18805/IJAR.B-4398

\begin{abstract}
Background: Tilapia (Oreochromis niloticus) is one of the most important aquaculture species in India. Streptococcus agalactiae is a highly debilitating pathogen of farmed tilapia. In this study, oxytetracycline (OTC) dose and delivery were standardized against $S$. agalactiae infection in genetically improved farmed tilapia (GIFT) and pharmacokinetics after oral administration was evaluated.

Methods: $L_{50}$ value of $S$. agalactiae was found to be $6.2 \times 10^{6} \mathrm{CFU} /$ fish. Two methods of drug delivery were investigated at three different doses of 50,70 and $90 \mathrm{mg} / \mathrm{kg}$ against the $S$. agalactiae infection. Pharmacokinetics of OTC was studied after per os administration of $100 \mathrm{mg} / \mathrm{kg}$ body weight per day and analysing the residues in kidney, liver and muscle at different time intervals. Result: Per os delivery of OTC $90 \mathrm{mg} / \mathrm{kg}$ controlled S. agalactiae infection and the withdrawal time of OTC to fall below MRL of 0.05 $\mu \mathrm{g} / \mathrm{g}$ at $30^{\circ} \mathrm{C}$ was 21 days in kidney and liver and 14 days in muscle. The study indicated that the S. agalactiae infection in tilapia could be controlled by OTC and fish can be marketed after providing a withdrawal period of 14 days.
\end{abstract}

Key words: GIFT, $\mathrm{LD}_{50}$, MRL (Maximum residue level), Oxytetracycline (OTC), Pharmacokinetics, Streptococcus agalactiae, Tilapia, Withdrawal time.

\section{INTRODUCTION}

Aquaculture is one of the fast-growing food production sectors in the world that contributed to $47 \%$ of the total fish production of 171 million tonnes in 2016 (FAO, 2018). Increased fishing pressure and biological alterations associated with climate change dwindled capture fisheries in India and worldwide. Oreochromis niloticus is an important species belonging to the Cichlidae family, native to Africa and Middle East regions with an estimated production of 5.3 million tonnes in 2016 that contributed to $10 \%$ of the global aquaculture production (FAO, 2018). In India, the production of tilapia is estimated to be 18,000 tons in 2016 with a $10 \%$ projected annual growth rate.

Of the several infectious agents that severely impede the economic development of aquaculture sector, Streptococcus agalactiae is one of the major pathogens responsible for the huge economic losses with an annual estimated to loss of about $\$ 40$ million in China (Chen et al. 2012). S. agalactiae known as Group B Streptococcus (GBS) is a Gram-positive coccus, recognized as a pathogen of humans and animals including fish (Bowater et al. 2018). GBS infections are reported in Nile tilapia (Oreochromis niloticus) (Li et al. 2014) and barcoo grunter (Scortum barcoo) (Liu et al. 2014). It causes septicaemia and meningitis in farmed and wild fish. GBS is first reported in hatchery-reared freshwater fish in the United States in 1966 (Robinson and Meyer 1966). Clinical signs of S. agalactiae infection include lethargy, anorexia, "C" shaped body posturing, erratic swimming and whirling (Evans et al. 2006).
Department of Fish Pathology and Health Management, Fisheries College and Research Institute, Thoothukudi-628 008, Tamil Nadu, India ${ }^{1}$ Kerala University of Fisheries and Ocean Studies, Panangad, Kochi-682 506, Kerala, India.

Corresponding Author: Mulloorpeedikayil Rosalind George, Department of Fish Pathology and Health Management, Fisheries College and Research Institute, Thoothukudi-628 008, Tamil Nadu, India. Email: rosalindmg@yahoo.com

How to cite this article: Kalaria, K.K., John, K.R., George, M.R. (2021). Standardization of Dose and Delivery of Oxytetracycline against Streptococcus agalactiae Infection in Genetically Improved Farmed Tilapia (GIFT). Indian Journal of Animal Research. DOI: 10.18805/IJAR.B-4398.

Submitted: 09-01-2021 Accepted: 23-08-2021 Online: 24-09-2021

S. agalactiae isolated from different geographic locations were found to be sensitive to ofloxacin, cephalosporin and tetracycline in Taiwan (Huang et al. 2014) and gentamicin, ciprofloxacin, chloramphenicol, erythromycin, sulfamethoxazole/ trimethoprim and tetracycline in Malaysia (Aisyhah et al. 2015). Among these, oxytetracycline (OTC) is an approved broad-spectrum antibiotic in aquaculture (Rigos and Troisi 2005), belonging to the tetracyclines class, a protein synthesis inhibitor. It is used for the treatment of fish bacterial diseases such as furunculosis, aeromonosis, pseudomonosis, lactococcosis and vibriosis (AliAbadi and MacNeil 2002; Cenavisa, 2016). Withdrawal time of OTC in Nile tilapia at different doses and by different route of 
administration has been reported previously (Chen et al. 2004; Paschoal et al. 2012; Soltan et al. 2013). But there are no reports regarding genetically improved farmed tilapia (GIFT) strain developed by the World Fish Centre, which exhibits higher growth performance compared to local strains of Nile tilapia. Hence the present study was conducted to standardize the dose and delivery route of OTC against $S$. agalactiae infection in GIFT and investigate the withdrawal time of OTC in tilapia (GIFT).

\section{MATERIALS AND METHODS Fish and bacterial strain}

Four hundred fifty juvenile tilapia (GIFT), averaging $22 \pm 5 \mathrm{~g}$ were procured from a local fish farm in 2019 and acclimatized for a period of 10 days in $20 \mathrm{~m}^{2}$ rectangular cement nursery tank after disinfection with $2 \mathrm{mg} / \mathrm{L}$ potassium permanganate. The fish were fed twice a day and water quality parameters were observed daily. Streptococcus agalactiae (ATCC-12386) culture was purchased from ATCC (Hi-media, Mumbai)

\section{Antibiotic sensitivity test}

Antimicrobial susceptibility testing was carried out by disk diffusion method on Mueller-Hinton agar. OTC discs with $30 \mu \mathrm{g}$ per disc were obtained commercially (HiMedia, Mumbai). Florfenicol disc at the same concentration was prepared after obtaining the drug from Meteoric biopharmaceuticals (Lalitha, 2004). The discs were placed on the agar plates after addition of $100 \mu \mathrm{l}$. agalactiae culture and incubated at $30 \pm 2^{\circ} \mathrm{C}$ for $24 \mathrm{~h}$ and the diameter of zone of inhibition in $\mathrm{mm}$ was measured.

\section{Estimation of LD $D_{50}$}

Juvenile tilapia (GIFT) were introduced into $100 \mathrm{~L}$ tanks having $60 \mathrm{~L}$ water with eight fish per tank. Tilapia were injected $0.1 \mathrm{ml}$ of serially diluted $\left(10^{-1}, 10^{-3}, 10^{-5}\right) \mathrm{S}$. agalactiae having a bacterial count of $6.2 \times 10^{9} \mathrm{CFU} / \mathrm{ml}$ intraperitoneally under anaesthesia by benzocaine $(10 \mathrm{mg} / \mathrm{L})$. First group received $6.2 \times 10^{8} \mathrm{CFU} / \mathrm{ml}$, second group $6.2 \times 10^{6}$ and third $6.2 \times 10^{4} \mathrm{CFU} / \mathrm{ml}\left(6.2 \times 10^{7}, 6.2 \times 10^{5}, 6.2 \times 10^{3} \mathrm{CFU} /\right.$ fish respectively). Control groups were injected with $0.1 \mathrm{ml}$ of sterile saline. Fish were fed once daily and water quality parameters were continuously observed. Samples of brain and kidney were collected from moribund fish for histopathology and dead fish were subjected to bacterial isolation. $\mathrm{LD}_{50}$ value was calculated by formula of Reed and Muench (1938).

\section{Minimum inhibitory concentration}

The minimum inhibitory concentration (MIC) of OTC was found out by slightly modified macrodilution method of CLSI (2012). The inoculum of $100 \mu \mathrm{l}$. agalactiae culture was added to $5 \mathrm{ml}$ TSB tubes prepared with different concentrations of OTC viz. 5, 10, 20, 30, 40, 50, 60, 70, 80, 90 and $100 \mu \mathrm{g} / \mathrm{ml}$ along with a control without antibiotic. Tubes were incubated for $24 \mathrm{~h}$ at $(30 \pm 2)^{\circ} \mathrm{C}$ and bacterial growth $(\mathrm{CFU} / \mathrm{ml})$ was calculated by serial dilution and incubation on TSA for $24 \mathrm{~h}$ at $(30 \pm 2)^{\circ} \mathrm{C}$.

\section{Experimental design for standardization of dose and delivery}

The fish (GIFT) $(20 \pm 5 \mathrm{~g})$ were first challenged with $0.1 \mathrm{ml}$ of $S$. agalactiae intraperitoneally after anesthetization with benzocaine $(10 \mathrm{mg} / \mathrm{L})$ and negative control with $0.1 \mathrm{ml}$ of sterile PBS. OTC was then administered at different concentrations by intraperitoneal injection and orally through feed (Table 1). The water quality parameters such as $\mathrm{pH}$, water temperature and dissolved oxygen, feeding behaviour, clinical signs of diseases and mortality were monitored. OTC by injection was administered at three doses at $24 \mathrm{~h}, 4^{\text {th }}$ day and $7^{\text {th }}$ day post-challenge in Groups 1,2 and 3. For groups 4, 5 and 6 OTC feed was prepared by mixing OTC solution into a commercial feed along with $10 \mu$ of soybean oil per gram to avoid antibiotic loss by hydro-solubilization during feeding. Fish were fed once a day at $2 \%$ of their body weight. The OTC treated groups were medicated for 10 consecutive days. During the observation period, samples of brain and kidney were taken from negative control, positive control and medicated groups for histopathology and bacteriology. The mortality data of OTC treated and control groups were compared by two-way Analysis of Variance (ANOVA). $P$ values $<0.05$ were considered significant.

\section{Histopathology}

Kidney and brain of moribund fish were collected from normal

Table 1: Experimental design for standardization of dose and delivery of oxytetracycline against S. agalactiae.

\begin{tabular}{lcl}
\hline Groups $^{*}$ & Dose $(\mathrm{mg} / \mathrm{Kg}$ of body weight) & Route of delivery \\
\hline Group 1 & 50 & Intraperitoneal injection \\
Group 2 & 70 & \\
Group 3 & 90 & Oral through feed \\
Group 4 & 50 & \\
Group 5 & 70 & No drug, control feed (positive control) \\
Group 6 & 90 & No drug, no challenge control feed (negative control) \\
Group 7 & Nil & Nil
\end{tabular}

${ }^{*}$ All groups were run in duplicate and had 15 fish each except 7 and 8 which had 10 fish each. All groups except 8 were challenged with S. agalactiae intraperitoneally. 
and infected fishes of $\mathrm{LD}_{50}$ analysis and medicated groups and fixed using neutral buffered formalin. Tissue sections were cut using standard procedures and stained in haematoxylin and eosin. The sections were examined and photographs taken under bright field in a trinocular microscope (Nikon, Japan).

\section{Pharmacokinetics of OTC in GIFT}

Healthy juvenile tilapia (GIFT), averaging $25 \pm 5 \mathrm{~g}$ were procured from a local fish farm. Fish were acclimatized for a period of 10 days in $500 \mathrm{~L}$ capacity tanks. The fish were fed once a day and water quality parameters were observed daily. The water temperature was $30 \pm 2^{\circ} \mathrm{C}$ during the course of the experiment. Two days before the experiment, the fish were starved until medication. OTC medicated feed was given to the fish for 7 days at the rate of $2 \%$ average body weight per day that was adjusted to a dose of $100 \mathrm{mg} \mathrm{OTC/}$ $\mathrm{kg}$ body weight per day. Medicated feed was prepared by dissolving OTC capsule (Pfizer limited) in distilled water and a mixture of $1.120 \mathrm{~g}$ of OTC in $336 \mathrm{~g}$ of feed and $10 \mu \mathrm{l}$ of soybean oil, which was used as a binder, was added to per gram commercial feed.

After 7 days of feeding the medicated diet, five fish were randomly selected from the tank at each sampling time at $3,6,12,18,24,36 \mathrm{~h}$ and 2, 3, 4, 7, 14 and 21-day intervals. Fish were decapitated and muscle, liver and kidney were collected. For each sampling, tissues were collected from 5 fishes and stored at $-80^{\circ} \mathrm{C}$. Control fish were sampled before the initiation of the study.

RIDASCREEN, Europroxima oxytetracycline kit (Rbiopharmneugen Pvt. Ltd Netherlands) was used for monitoring the oxytetracycline residues in fish. Samples were analysed after 21 days of sampling by the oxytetracycline ELISA kit having a limit of detection (LOD) of $2 \mathrm{ppb}(\mu \mathrm{g} / \mathrm{L})$ according to the manufacturer's instructions. Briefly, samples were homogenized and transferred into 15 $\mathrm{ml}$ plastic tubes and vortexed for $10 \mathrm{~min}$ after adding $3 \mathrm{ml}$ of Mcllvaine buffer. The mixture was then centrifuged at 2000 $\mathrm{g}$ for $10 \mathrm{~min}$. The supernatant $(50 \mu \mathrm{l})$ was pipetted into new tube and $200 \mu$ l of dilution buffer was added and absorbance values were measured in an ELISA reader at $450 \mathrm{~nm}$. The results were used for calculating the concentration of antibiotic in tissues from the calibration curve plotted for the concentration standards (Fig 1).

\section{RESULTS AND DISCUSSION Antibiotic sensitivity of $S$. agalactiae}

Streptococcus agalactiae is a major problem in tilapia farming responsible for high mortality. The antibiotic susceptibility test of $S$. agalactiae showed that the bacteria was sensitive to both oxytetracycline and florfenicol with higher sensitivity to OTC. Zone of inhibition of OTC was 38 $\mathrm{mm}$ while florfenicol was $27 \mathrm{~mm}$. This result was similar to the earlier reports on the pathogen sensitivity to OTC (Ali et al. 2010; Najiah et al. 2012; Reyes et al. 2019). The antibiotic was reported to be effective in controlling mortality in Nile tilapia infected with S. agalactiae (Faria et al. 2014; Mariotto et al. 2018).

\section{LD $_{50}$ of $S$. agalactiae in GIFT and histopathology}

Infected tilapia injected with serially diluted $S$. agalactiae showed clinical signs such as spiral swimming, decayed caudal fin, swollen abdomen, exophthalmia and lesions on body (Fig 2). No clinical signs or mortality was recorded in the control group. Mortality started after $30 \mathrm{~h}$ of injection of S. agalactiae at $6.2 \times 10^{7} \mathrm{CFU} /$ fish and continued up to 5 days. Cumulative mortality is given in Fig 3. S. agalactiae was also re-isolated from the dead and moribund fish challenged by i.p. injection and identified by 16s $r$ RNA sequence analysis indicating that the death/morbidity was due to $S$. agalactiae. The $L_{50}$ of $S$. agalactiae in tilapia was found to be $6.2 \times 10^{6} \mathrm{CFU} / \mathrm{fish}$, which is similar to an earlier study of two bacterial strains from Nile tilapia that had the $\mathrm{LD}_{50}$ value of $6.8 \times 10^{6}$ and $5.3 \times 10^{6} \mathrm{CFU} /$ fish (Wang et al. 2013). However, it was lower to the $L_{50}$ range of $1.72 \times 10^{7}$

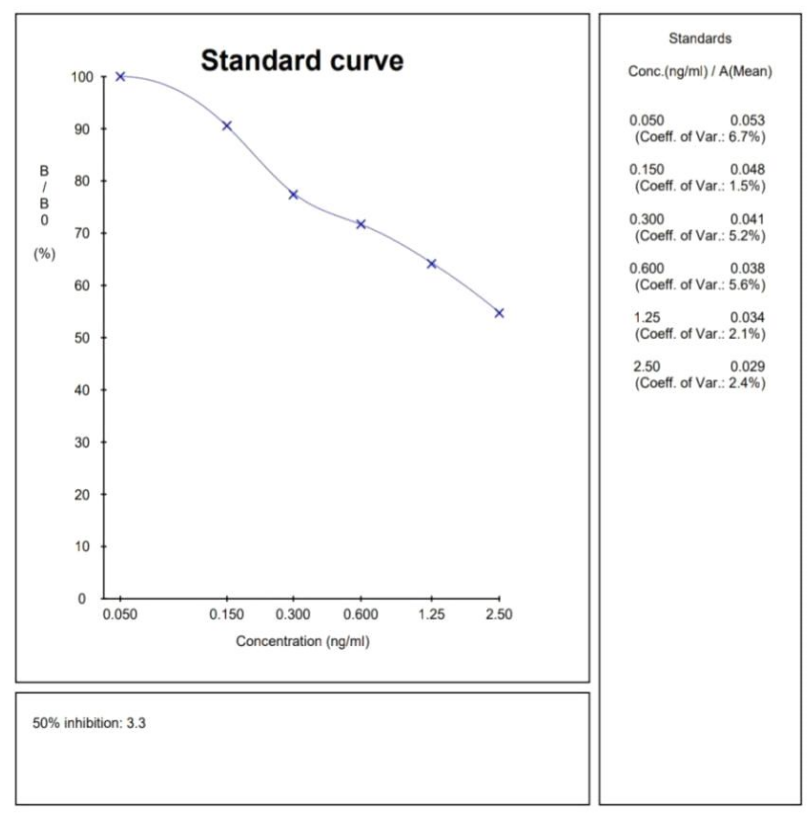

Fig 1: Standard curve for estimation of OTC by using ELISA.

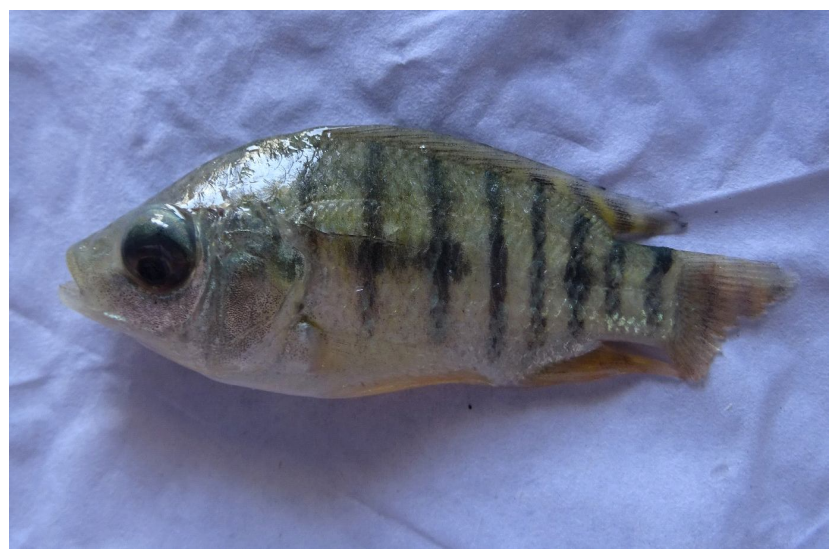

Fig 2: S. agalactiae infected fish with decayed caudal fin and exophthalmia. 


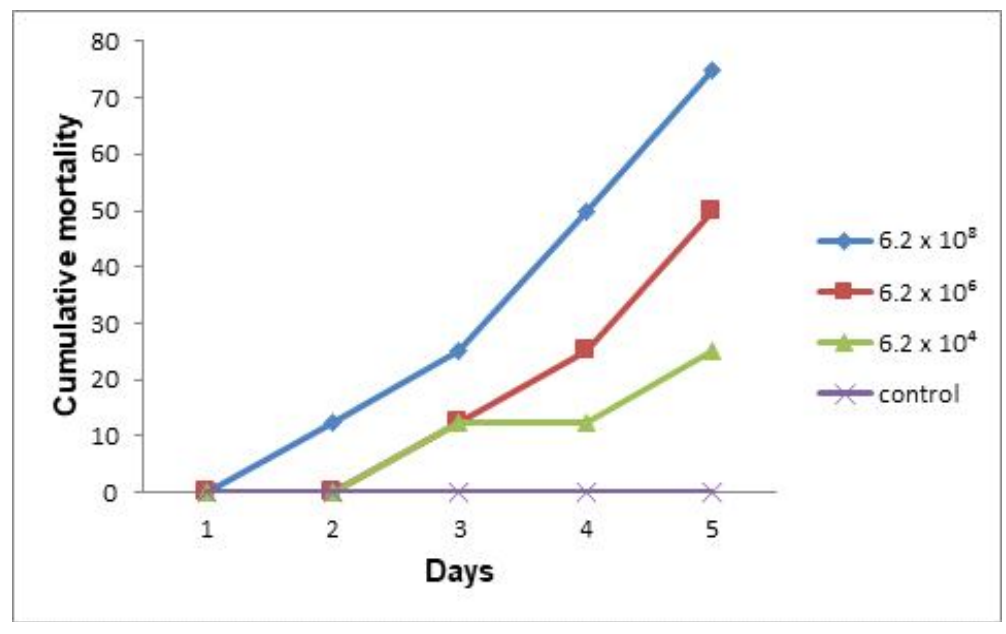

Fig 3: Cumulative mortality of tilapia (GIFT) infected with $S$. agalactiae.

CFU to $6.3 \times 10^{9} \mathrm{CFU} / \mathrm{ml}$ reported for adult tilapia (NurNazifah et al. 2011) indicating the strain in this study is more virulent. Clinical signs such as lethargy, anorexia, erratic swimming and whirling, decayed caudal fin, swollen abdomen, exophthalmia and lesions on body observed during the study were similar to those reported earlier in tilapia for S. agalactiae infections (Evans et al. 2006).

Histopathological lesions such as severe tubulonephrosis, congested glomerulus and sharply decreased hemopoietic tissue observed in the kidney (Fig 4,5$)$ of the infected fish and meningeal congestion and vacuolar degeneration of the neuron in the brain (Fig 6,7) were similar to the observation of $\mathrm{He}$ et al. (2017).

\section{Minimum inhibitory concentration (MIC) of OTC against S. agalactiae}

MIC of OTC noticed in the present study was $80 \mu \mathrm{g} / \mathrm{ml}$ (Table 2), which was higher than the earlier report of $0.5-8.0 \mu \mathrm{g} / \mathrm{ml}$ for Streptococcus isolates obtained from the diseased tilapia (Maisak et al. 1995) and 0.6 to $31.25 \mu \mathrm{g} / \mathrm{ml}$ of the 29 strains of S. agalactiae isolated from Nile tilapia (Faria et al. 2014).

\section{Standardization of dose and delivery}

No mortality or clinical signs of disease were observed in the negative control groups during the experimental period. All control groups were euthanized by benzocaine overdose and subjected to bacteriological assessment, which produced negative results for bacterial pathogens. All positive control groups challenged with $S$. agalactiae at $6.2 \times 10^{7} \mathrm{CFU} /$ fish exhibited a cumulative mortality of $70 \%$ during the treatment period. The main clinical signs observed were spiral swimming, decayed caudal fin, swollen abdomen, exophthalmia and lesions on the body. Treatment by injection was very stressful for fish as seen from the mortality in all three doses that ranged from 30 to $63.3 \%$. The cumulative mortality recorded in the both types of drug delivery is shown in the Fig 8 and 9 . Treatment by medicated feed at an effective dose of $50 \mathrm{mg} / \mathrm{kg}$ body weight was unable to control the mortality and had a cumulative mortality of

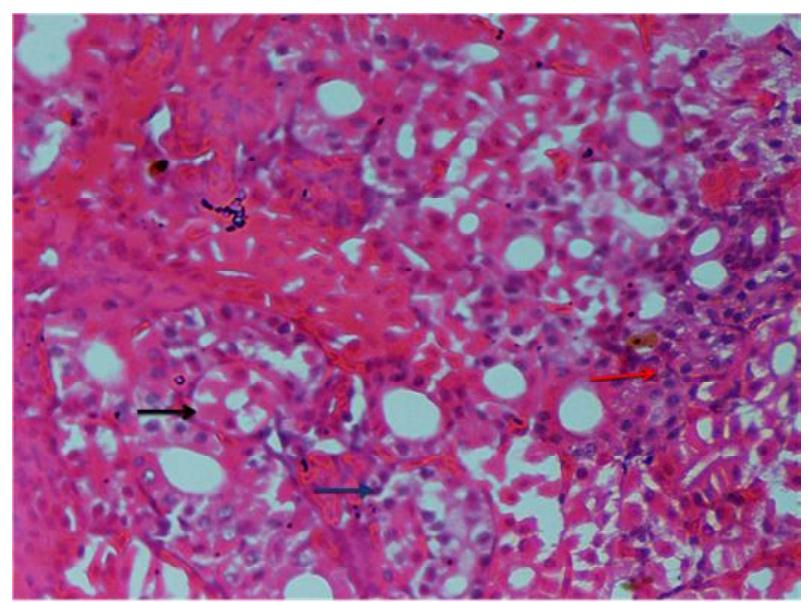

Fig 4: Kidney from uninfected fish stained with H\&E showing renal tubules (black arrow), hemopoietic tissue (red arrow) and normal renal corpuscles, showing glomerulus (blue arrow).

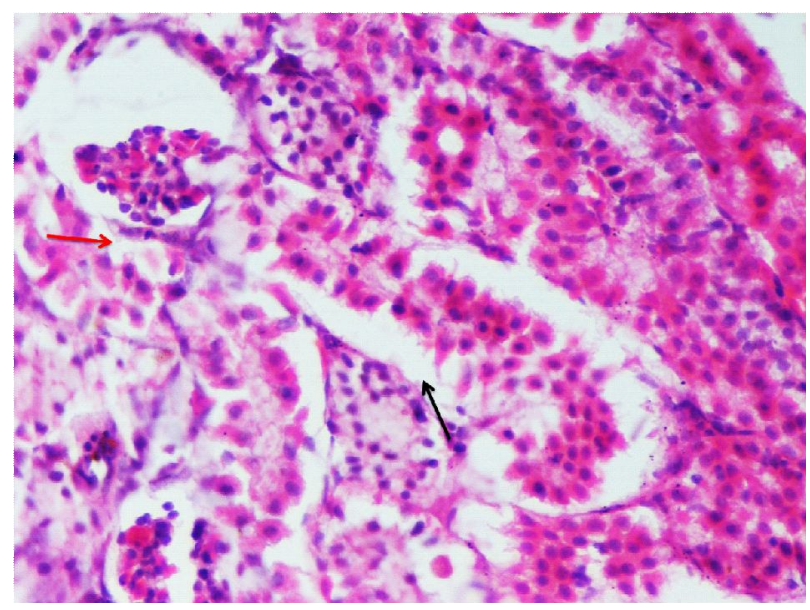

Fig 5: Kidney from fish injected with $10^{8}$ cells of $S$. agalactiae showing severe tubulonephrosis (black arrow) and a sharp decrease of hemopoietic tissue, with congested glomerulus and necrotic debris in the Bowman's capsule (red arrow). 
$40 \%$. The dose of $70 \mathrm{mg} / \mathrm{kg}$ and $90 \mathrm{mg} / \mathrm{kg}$ body weight were efficient to control mortality with low cumulative mortality of $26.6 \%$ and $20 \%$. The high survival rate of infected tilapia treated with $70 \mathrm{mg} / \mathrm{kg}$ OTC incorporated feed showed that

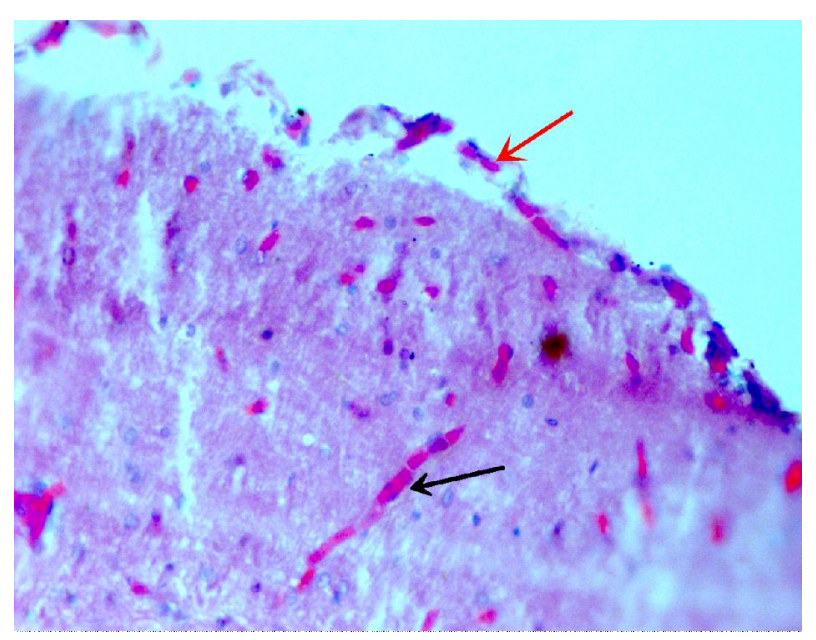

Fig 6: Brain from uninfected fish $(600 \mathrm{X})$ showing brain microvessels (black arrow) and thin meninges (red arrow).

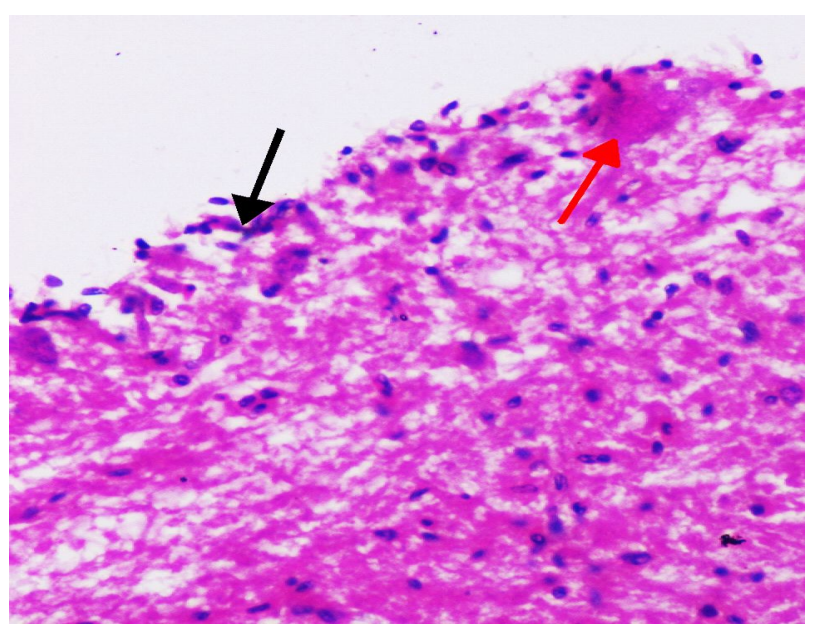

Fig 7: Brain from fish $(600 \mathrm{X})$ injected with $10^{8}$ cells of $S$. agalactiae showing meningeal congestion (black arrow) and vacuolar degeneration (red arrow).

Table 2: MIC of OTC against Streptococcus agalactiae.

\begin{tabular}{lcc}
\hline No. & Concentration of OTC $(\mu \mathrm{g} / \mathrm{ml})$ & Growth \\
\hline 1 & 5 & + \\
2 & 10 & + \\
3 & 20 & + \\
4 & 30 & + \\
5 & 40 & + \\
6 & 50 & + \\
7 & 60 & + \\
8 & 70 & + \\
9 & 80 & - \\
10 & 90 & - \\
11 & 100 & - \\
\hline
\end{tabular}

Table 3: OTC concentration $(\mu \mathrm{g} / \mathrm{g})$ in the tissues of tilapia (GIFT) held at $30 \pm 2^{\circ} \mathrm{C}$.

\begin{tabular}{lccc}
\hline Sampling time & Kidney & Liver & Muscle \\
\hline $3 \mathrm{~h}$ & 0.332 & 0.208 & 0.293 \\
$6 \mathrm{~h}$ & 0.312 & 0.187 & 0.216 \\
$12 \mathrm{~h}$ & 0.264 & 0.175 & 0.195 \\
$18 \mathrm{~h}$ & 0.253 & 0.166 & 0.138 \\
$24 \mathrm{~h}$ & 0.227 & 0.142 & 0.130 \\
$36 \mathrm{~h}$ & 0.175 & 0.125 & 0.125 \\
$48 \mathrm{~h}$ & 0.142 & 0.115 & 0.118 \\
$3 \mathrm{~d}$ & 0.133 & 0.106 & 0.113 \\
$4 \mathrm{~d}$ & 0.112 & 0.096 & 0.100 \\
$7 \mathrm{D}$ & 0.073 & 0.077 & 0.088 \\
$14 \mathrm{~d}$ & 0.094 & 0.062 & 0.046 \\
$21 \mathrm{~d}$ & 0.049 & 0.046 & 0.038 \\
Control & $\mathrm{ND}$ & $\mathrm{ND}$ & $\mathrm{ND}$ \\
\hline
\end{tabular}

ND* - Not detected.

the drug and delivery method was better than earlier reports where the survival was only $56 \%$ (Swastika and Niezha, 2016). The histological changes noticed in positive control were similar to those found in $L D_{50}$ studies. There were minimal changes compared to control tissues in the samples collected from medicated fish (90 mg/kg) (Fig 10 and 11). Two-way ANOVA revealed that there is no significant difference $(p>0.05)$ in treated groups.

\section{Pharmacokinetics of OTC}

No mortality was recorded during the experiment and water quality parameters were within normal culture conditions with the temperature at $30 \pm 2^{\circ} \mathrm{C}$, dissolved oxygen $>6 \mathrm{mg} / \mathrm{L}$ and $\mathrm{pH} 7.38 \pm 0.03$. In control fish tissues, OTC was not detected. Concentration of OTC in different tissue samples is given in Table 3. In liver, OTC concentration was under the maximum residue level (MRL) value on 21 day. In kidney on 21 day, OTC was under MRL and in muscle OTC was under MRL on $14^{\text {th }}$ day. According to food and drug administration, the maximum residual level of antibiotics in fish before human consumption is $0.05 \mu \mathrm{g} / \mathrm{g}$. According to Aquatic Animal Drug Approval Partnership (FDA 2001), the withdrawal time of oxytetracycline dihydrate for disease control in salmonids and catfish is 21 days. Reports from the temperate countries on the withdrawal time of OTC from tissues indicate wide variations in the time required for the antibiotic to fall below MRL depending on the fish species and the temperature of rearing. Withdrawal time of OTC was 21 days in Cyprinus carpio at a water temperature $20^{\circ} \mathrm{C}$ (Grondel et al. 1987); 60 days in rainbow trout above $12^{\circ} \mathrm{C}$ (Jacobsen, 1989) and 25 days in grass carp at $21 \pm 1^{\circ} \mathrm{C}$ after 7 days oral administration of OTC at $100 \mathrm{mg} / \mathrm{kg}$ per day (Zhang and Li, 2007). Following a single dose of 100 $\mathrm{mg} / \mathrm{kg}$ by oral administration, the OTC concentrations in muscle of perch and black seabream was reported below $0.05 \mathrm{ug} / \mathrm{g}$ after 30 days at $17.3 \pm 0.8^{\circ} \mathrm{C}$ (Wang et al. 2004). In the present study, OTC concentrations in the kidney and 


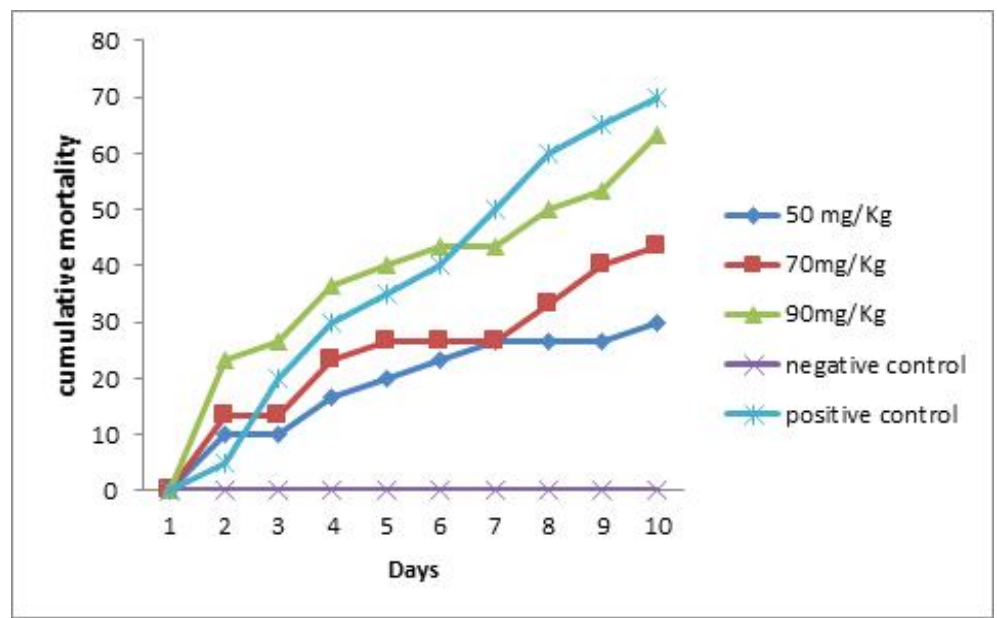

Fig 8: Cumulative mortality of fish observed in treatment with oxytetracycline by intraperitoneal injection.

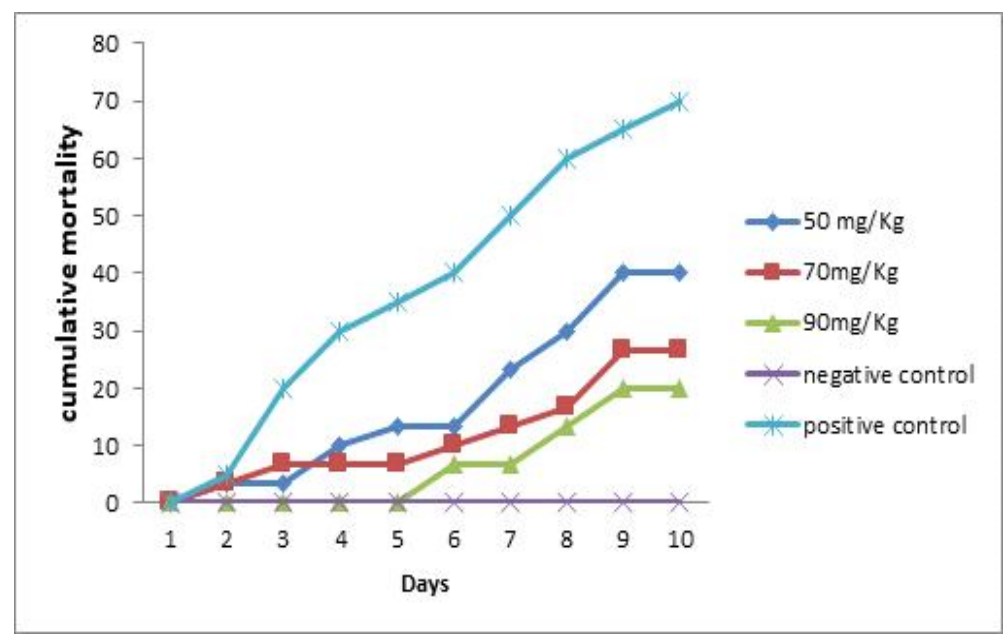

Fig 9: Cumulative mortality of fish observed in treatment with OTC through medicated feed.

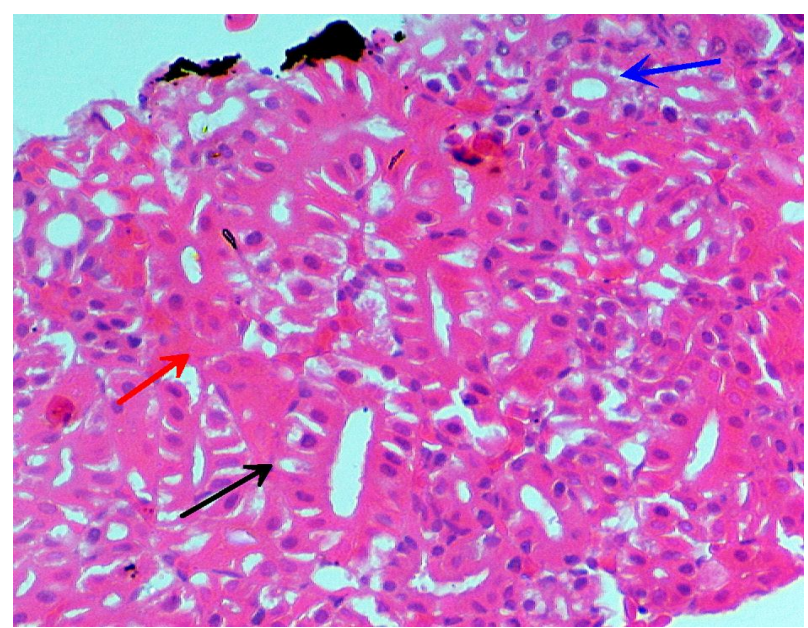

Fig 10: Kidney of fish $(600 \mathrm{X})$ fed on $90 \mathrm{mg} / \mathrm{kg}$ OTC treated medicated feed with normal renal tubules (black arrow) and hemopoietic tissue (red arrow).

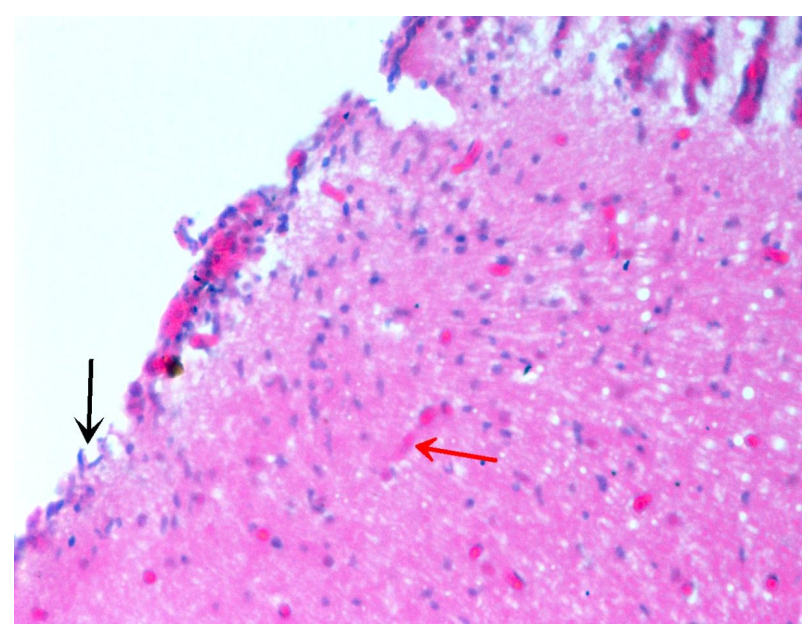

Fig 11: Brain of fish (60X) fed on $90 \mathrm{mg} / \mathrm{kg}$ OTC treated medicated feed with thin meninges (black arrow) and brain microvessels (red arrow). 
liver fell below the stipulated MRL of $0.05 \mu \mathrm{g} / \mathrm{g}$ in 21 days and in muscle it fell below the MRL in 14 days at $30 \pm 2^{\circ} \mathrm{C}$ after oral administration of OTC at the rate of $100 \mathrm{mg} / \mathrm{kg}$ for 7 days. In earlier studies conducted in Oreochromis niloticus with OTC administered at $40,80,120 \mathrm{mg} / \mathrm{kg}$ at water temperature $29.17^{\circ} \mathrm{C}$, the drug was eliminated from the tissues after 21 days (Soltan et al. 2013).

\section{CONCLUSION}

Thus, the current study indicated that the $S$. agalactiae infection in GIFT can be controlled by the administration of OTC at $70 \mathrm{mg} / \mathrm{kg}$ applied through feed and the fish fillets would be ready for consumption after 14 days of the last dose at the tropical water temperatures of about $30^{\circ} \mathrm{C}$. Though the application of the antibiotics in aquaculture is restricted widely, controlled and cautious application of the safe quantity of the antibiotic orally could be taken up for controlling the $S$. agalactiae infection in tilapia (GIFT).

\section{ACKNOWLEDGEMENT}

Funding support for the National Surveillance Programme for Aquatic Animal Diseases (sub project no - 21) by NFDBICAR-NBFGR, Lucknow under which the investigation was carried out is gratefully acknowledged.

\section{REFERENCES}

Aisyhah, M.A.S., Amal, M.N.A., Zamri-Saad, M., Siti-Zahrah, A. and Shaqinah, N.N. (2015). Streptococcus agalactiae isolates from cultured fishes in Malaysia manifesting low resistance pattern towards selected antibiotics. Journal of Fish Diseases. 38: 1093-1098.

Ali Abadi, F.S. and MacNeil, J.D. (2002). FAO FNP 41/14 Oxytetracycline. Available from http://www.fao.org/fileadmin/user_upload/ vetdrug/docs/41-14-oxytetracycline.pdf.

Ali, A., Hassan, D., Saleha, A.A., Siti, K.B. and Milud, A. (2010). Streptococcus agalactiae the etiological agent of mass mortality in farmed red tilapia (Oreochromis $s p$.). Journal of Animal and Veterinary Advances. 9: 2640-2646.

Bowater, R.O., Dennis, M.M., Blyde, D., Stone, B., Barnes, A.C., Delamare Deboutteville, J. and Jones, R. (2018). Epizootics of Streptococcus agalactiae infection in captive rays from Queensland, Australia. Journal of Fish Diseases. 41: 223-232.

Cenavisa (2016). Aquacen Oxitetraciclina Hidrocloruro $1000 \mathrm{mg} / \mathrm{g}$. URL:http://www.cenavisa.es/products/view/81/aquacen_ oxitetraciclina_hidroclor uro_1000_mgg.

Chen, C.Y., Getchell, R.G., Wooster, G.A., Craigmill, A.L. and Bowser, P.R. (2004). Oxytetracycline residues in four species of fish after 10-day oral dosing in feed. Journal of Aquatic Animal Health. 16: 208-219.

Chen, M., Li, L.P., Wang, R., Liang, W.W., Huang, Y., Li, J. and Gan, $X$. (2012). PCR detection and PFGE genotype analyses of streptococcal clinical isolates from tilapia in China. Veterinary Microbiology. 159: 526530.

Clinical and Laboratory Standards Institute. (2012). Methods for dilution antimicrobial susceptibility tests for bacteria that grow aerobically; Approved Standard-Ninth Edition. CLSI Document M07-A9.
Evans, J.J., Klesius, P.H. and Shoemaker, C.A. (2006). An overview of Streptococcus in warm water fish. Aquaculture Health International. 7: 10-14.

FAO. (2018). The state of world fisheries and aquaculture 2018. Rome: Food and Agriculture Organization of the United Nations.

Faria, F.C., Leal, C.A.G., Carvalho Castro, G.A., Leite, R.C. and Figueiredo, H.C.P. (2014). Carrier state induced by oxytetracycline therapy against streptococcosis in Nile tilapia, Oreochromis niloticus (L.). Journal of Fish Diseases. 37: 853-857.

FDA. (2001). Secondary direct food additives permitted in food for human consumption. Federal Register. 66: 33829-33830.

Grondel, J.L., Nouws, J.F. M., De Jong, M., Schutte, A.R. and Driessens, F. (1987). Pharmacokinetics and tissue distribution of oxytetracycline in carp, Cyprinus carpio L., following different routes of administration. Journal of Fish Diseases. 10: 153-163.

He, Y., Huang, J.L., Wang, K.Y., Chen, D.F., Geng, Y., Huang, X.L and Lai, W.M. (2017). Pathogenicity of Streptococcus agalactiae in Oreochromis niloticus Oncotarget, 5. Retrieved from https://www.oncotarget.com/article/23551/text/

Huang, T.M., Hsu, C.C. and Chen, M.M. (2014). Antimicrobial susceptibility of fish Streptococcaceae and drug resistance determinants of erythromycin-and tetracycline-resistant Lactococcus isolated in Taiwan. Taiwan Veterinary Journal. 40: 131-138.

Jacobsen, M.D. (1989). Withdrawal times of freshwater rainbow trout, Salmo gairdneri Richardson, after treatment with oxolinic acid, oxytetracycline and trimethoprim. Journal of Fish Diseases. 12: 29-36.

Lalitha, M.K. (2004). Manual on antimicrobial susceptibility testing. Performance standards for antimicrobial testing: Twelfth Informational Supplement. 56238, pp.454-456.

Li, Y.W., Liu, L., Huang, P.R., Fang, W., Luo, Z.P., Peng, H.L. and $\mathrm{Li}$, A.X. (2014). Chronic streptococcosis in Nile tilapia, Oreochromis niloticus (L.), caused by Streptococcus agalactiae. Journal of Fish Diseases. 37: 757-763.

Liu, L., Li, Y.W., He, R.Z., Xiao, X.X., Zhang, X., Su, Y.L. and Li, A.X. (2014). Outbreak of Streptococcus agalactiae infection in barcoo grunter, Scortum barcoo (McCulloch and Waite), in an intensive fish farm in China. Journal of Fish Diseases. 37: 1067-1072.

Maisak, H., Tipmongkolsilp, N. and Wongtavatchai, J. (1995). Minimum inhibitory concentrations of antimicrobials against clinical Vibrio and Streptococcus isolated from aquaculture. Bondad-Reantaso MG, Jones JB, Corsin F, Aoki T. Diseases in Asian Aquaculture II. Selangor, Malaysia: Fish Health Section, Asian Fisheries Society. 309-316.

Mariotto, I.D.F., Wosiacki, S.R. and Ferrante, M. (2018). Efficacy of oxytetracycline in the treatment of Streptococcus agalactiae in tilapia at different breeding temperatures. Pubvet. 12 (10): 181.

Najiah, M., Aqilah, N.I., Lee, K.L., Khairulbariyyah, Z., Mithun, S., Jalal, K.C.A. and Nadirah, M. (2012). Massive mortality associated with Streptococcus agalactiae infection in cage-cultured red hybrid tilapia Oreochromis niloticus in Como River, Kenyir Lake, Malaysia. Journal of Biological Sciences. 12: 438-442. 
Nur-Nazifah, M., Firdaus-Nawi, M., Sabri, M.Y., Siti-Zahrah, A. and ZamriSaad, M. (2011). Determination of $L_{50}$ for Streptococcus agalactiae and Staphylococcus aureus infections in tilapia. Jurnal Veterinar Malaysia. 23: 22-27.

Paschoal, J.A.R., Bicudo, Á.J., Cyrino, J.E.P., Reyes, F.G.R. and Rath, S. (2012). Depletion study and estimation of the withdrawal period for oxytetracycline in tilapia cultured in Brazil. Journal of Veterinary Pharmacology and Therapeutics. 35: $90-96$

Reed, L.J. and Muench, H. (1938). A simple method of estimating fifty per cent endpoints. American Journal of Epidemiology. 27: 493-497.

Reyes, A.T., Fajardo, L.J. and Abando, A.K.Y. (2019). Antibiotic susceptibility of Streptococcus agalactiae isolated from Tilapia pond sediment in Lubao, Pampanga, Philippines. Journal of Drug Delivery and Therapeutics. 9: 370-375.

Rigos, G. and Troisi, G.M. (2005). Antibacterial agents in Mediterranean finfish farming: A synopsis of drug pharmacokinetics in important euryhaline fish species and possible environmental implications. Reviews in Fish Biology and Fisheries. 15: 53-73.

Robinson J.A. and Meyer F.P. (1966) Streptococcal fish pathogen. Journal of Bacteriology. 92: 512.
Soltan, M.A., Agouz, H.M. and Mohamed, M.G. (2013). Effect of oxytetracycline and florfenicol drugs on the physiological activities and its residues of Oreochromis niloticus. Egyptian Journal of Aquatic Biology and Fisheries. 287: 18-28.

Swastika Dita Soraya and Niezha Eka Putri (2016). Efficacy of oxytetracycline against streptococcosis infection on tilapia fish farming. Meeting abstracts Asia pacific aquaculture, World Aquaculture Society https://www.was.org/meetings/ ShowAbstract.aspx?ld=43122.

Wang, Q., Liu, Q. and Li, J. (2004). Tissue distribution and elimination of oxytetracycline in perch Lateolabras janopicus and black seabream (Sparus macrocephalus) following oral administration. Aquaculture. 237: 31-40.

Wang, K., Chen, D., Huang, L., Lian, H., Wang, J., Xiao, D. and Lai, W. M. (2013). Isolation and characterization of Streptococcus agalactiae from Nile Tilapia Oreochromis niloticus in China. African Journal of Microbiology Research. 7: 317-323.

Zhang, Q. and Li, X. (2007). Pharmacokinetics and residue elimination of oxytetracycline in grass carp, Ctenopharyngodon idellus. Aquaculture. 272: 140-145. 